\title{
Surface Quality Comparison of Down and Up cut Technique on CNC Milling Machine toward ST-37 Steel Material
}

\section{Perbandingan Kualitas Permukaan Metode Down dan up Milling pada Mesin Frais CNC terhadap Material Baja ST-37}

\author{
Yufrizal A ${ }^{1}$, Eko Indrawan ${ }^{1 *}$, Abdul Aziz ${ }^{1}$, Rifelino ${ }^{1}$, Rahmad Fajri Ula Agus Hendrianto ${ }^{1}$
}

\begin{abstract}
The purpose of this research is comparing down and up cut technique on milling process toward ST-37 steel material by using HSS $\emptyset 12 \mathrm{~mm}$ end mill cutter. The surface roughness result of down cut technique is achieved Ra $2.39 \mu \mathrm{m}$ which is equivalent to $N 7$ roughness level at lowest cutting speed $20 \mathrm{~m} / \mathrm{mnt}$. Moreover, the highest roughness Ra $3.61 \mu \mathrm{m}$ obtained at highest cutting speed $30 \mathrm{~m} / \mathrm{mnt}$ which is equivalent to $\mathrm{N8}$ roughness level. While, the quality of up cut technique yield the roughnes Ra $3.94 \mu \mathrm{m}$, equivalent to $\mathrm{N8}$ roughness level at lowest cutting speed $20 \mathrm{~m} / \mathrm{minute}$, whilst, $R a 6.01 \mu \mathrm{m}$ that equivalent to $N 9$ roughness level on highest cutting speed condition $30 \mathrm{~m} /$ minute. The surface roughnes value achieved between N7-N9 level (ISO). Down cut technique is recommended in order to achieve good surface quality, because it could be generate lower surface roughness on material.
\end{abstract}

Keywords

Surface quality, down and up cut technique, CNC milling machine, ST-37 steel.

\begin{abstract}
Abstrak
Tujuan dari penelitian ini adalah membandingkan teknik down cut dan up cut pada proses freis terhadap material baja ST-37 dengan menggunakan end mill cutter diameter Ø12 mm. Hasil kekasaran permukaan dari teknik down cut adalah Ra 2,39 $\mu$ m yang setara dengan level kekasaran N7 pada kecepatan potong terendah $20 \mathrm{~m} / \mathrm{mnt}$. Selanjutnya, kekasaran tertinggi Ra 3,61 $\mu \mathrm{m}$ diperoleh pada kecepatan potong tertiggi $30 \mathrm{~m} / \mathrm{mnt}$ yang setara dengan level kekasaran N8. Sementara itu, kualitas teknik up cut menghasilkan kekasaran Ra 3,94 $\mu$ m yang setara dengan level kekasaran N8 pada kecepatan potong terendah $20 \mathrm{~m} / \mathrm{mnt}$, sedangkan Ra 6,01 $\mu \mathrm{m}$ yang setara dengan level $\mathrm{N} 9$ pada kecepatan potong tertinggi $30 \mathrm{~m} / \mathrm{mnt}$. Harga kekasaran permukaan material diperoleh di antara level N7-N9 (nomor kekasaran ISO). Teknik down cut direkomendasikan untuk memperoleh kualitas permukaan yang baik, karena teknik ini dapat menghasilkan kekasaran permukaan yang lebih rendah pada benda kerja.
\end{abstract}

\section{Kata Kunci}

Kualitas permukaan, teknik down dan up cut, mesin frais CNC, baja ST-37.

1 Jurusan Teknik Mesin, Universitas Negeri Padang

Fakultas Teknik, Kampus UNP Air Tawar, Jl. Prof. Dr. Hamka, Padang

*ekoindrawan@ft.unp.ac.id

Submitted November 19, 2019. Accepted : December 17, 2019. Published : January 15, 2020. 


\section{PENDAHULUAN}

Perkembangan zaman yang disertai dengan perkembangan ilmu pengetahuan dan teknologi yang pesat saat ini menciptakan era globalisasi dan keterbukaan. Hal ini menuntut setiap individu untuk ikut serta di dalamnya, sehingga sumber daya manusianya harus menguasai IPTEK serta mampu untuk mengaplikasikannya dalam kehidupan. Teknik Mesin adalah cabang ilmu rekayasa (engineering) yang telah berkembang seiring dengan perkembangan zaman yang disertai dengan IPTEK. Metrologi disebut juga Ilmu Pengukuran adalah disiplin ilmu yang mempelajari jenis-jenis alat ukur keteknikan, metode pengukuran, kalibrasi dan akurasi di bidang industri, ilmu pengetahuan dan teknologi [1]. Teknik Mesin dapat diartikan ilmu rekayasa yang mengaplikasikan prinsip fisika untuk analisis, desain, pengembangan, pembuatan, operasi serta pemeliharaan perangkat dan komponen mekanikal.

Mesin produksi merupakan salah satu bidang dalam teknik mesin yang perkembanganya tidak bisa terpisahkan dari pertumbuhan peningkatan industri. karena memegang peranan besar dalam rekayasa dan reparasi produksi logam. Hampir tidak mungkin suatu pabrik tanpa melibatkan unsur mesin produksi. Salah satu jenis dari mesin produksi adalah mesin CNC (Computer Numerical Control), dimana dalam pengoperasianya sudah lebih canggih dibanding dengan mesin perkakas konvesional. Secara sederhana mesin CNC dapat diartikan suatu mesin perkakas yang dikendalikan dengan perintah angka atau numeric oleh komputer.

Jenis dari mesin CNC salah satunya adalah mesin frais CNC merupakan mesin yang sering digunakan di Industri, akademik maupun pelatihan. Mesin frais CNC secara singkat dapat diartikan mesin frais yang dalam proses penyayatan benda kerja oleh pisau frais atau pahat dibantu dengan kontrol numerik komputer atau CNC[2]. Secara prinsip kerja mesin frais CNC sama dengan mesin frais konvesional manual, perbedaan mendasar terletak pada cara pengoperasianya. Bila mesin frais konvensional cara pengopersaianya masih secara manual atau kata lain operator langsung yang menggerakan bagian-bagian dari mesin sedangkan padan mesin frais CNC operator hanya membuat, mengedit dan menginput program, maka mesin akan memproses program dan menjalankanya secara otomatis mengikuti perintah program yang telah diimput dengan kontrol komputerisasi.

Parameter yang harus diperhitungkan pada proses frais yaitu kecepatan potong, feeding dan kedalaman pemotongan. Kodisi pemotongan tersebut memberikan kontribusi terhadap terhadap umur pisau frais dan kualitas permukaan yang dikerjakan, sehingga pemilihan parameternya haruslah mendapatkan perhatian khusus[3]. Pengerjaan pada proses pengefraisan perlu juga mengetahui metode penyayatan atau metode pengefraisan yang akan digunakan. Metode pengefraisan ditentukan berdasarkan arah relatif gerak makan meja mesin frais terhadap putaran pisau. Terdapat 2 metode pengefraisan, yaitu metode downcut dan metode uppercut [4]. Secara singkat metode penyayatan downcut dapat diartikan dengan metode pengefreisan turun, arah putaran mata potong pada metode ini searah dengan gerak makan meja mesin frais. Sedangkan metode uppercut merupakan pengefraisan naik dengan arah putaran mata potong berlawanan arah dengan gerak makan meja mesin frais.

Pada proses pengefraisan metode penyayatan juga perlu diperhatikan karena mempengaruhi kualitas permukaan benda kerja yang dihasilkan. Hasil penelitian bahwa kecepatan putaran spindel $740 \mathrm{rpm}$ dengan sudut potong $80^{\circ}$ menghasilkan permukaan yang lebih halus yaitu $(\Sigma \mathrm{Rap})=5,76 \mu \mathrm{m}$ atau pada kelas kekasaran $\mathrm{N} 9$ sedangkan kecepatan putaran spindel $440 \mathrm{rpm}$ dengan sudut potong $80^{\circ}$ menghasilkan permukaan yang kasar $(\Sigma$ Rap $)=11,47 \mu \mathrm{m}$ dengan kelas kekasaran permukaan $\mathrm{N} 10$ [5]. Hasil penelitian lain semakin tinggi nilai feeding pada proses pembubutan, maka nilai rata-rata kekasaran permukaan yang diperoleh semakin rendah bila dibandingkan dengan dengan harga rata-rata kekasaran hasil pembubutan yang mengunakan nilai feeding yang rendah [6]. 
Kualitas suatu permukaan memiliki peranan yang sangat penting dalam suatu komponen produk khususnya yang menyangkut masalah gesekan pelumasan, keausan, tahanan terhadap kelelahan dan sebagainya. Kekasaran permukaan merupakan salah satu kualitas yang memiliki peran sangat penting dari suatu komponen mesin yang bersinggungan atau bergesekan denngan komponen lainnya dalam suatu konstruksi mesin. Kekasaran permukaan material setelah melalui proses pemesinan dipengaruhi oleh beberapa faktor, diantaranya: kondisi pemotongan, jenis pahat yang digunakan, kualitas mesin yang dioperasikan, dan jenis material. Kondisi pemotongan memiliki peran yang sangat penting untik mencapai kualitas pemesinan yang baik. Gerak makan, kecepatan potong dan kedalaman pemotongan merupakan kondisi pemotongan primer dalam proses pemesinan. Pada proses freis, dua metode umum yang sering diaplikasikan selama proses pemesinan berlangsung, yaitu: down cut dan up cut. Teknik down cut terjadi apabila arah putaran cutter searah terhadap arah gerakan benda kerja, sedangkan jika arah putaran cutter berlawanan arah terhadap arah gerakan benda kerja maka kondisi tersebut disebut sebagai teknik up cut.

\section{METODE PENELITIAN}

Penelitian ini merupakan penelitian eksperimen yang membandingkan kualitas permukaan hasil sayatan pada Baja ST-37 antara metode downcut dengan uppercut menggunakan mesin frais CNC. Metode penelitian eksperimen dapat diartikan sebagai metode penelitian yang digunakan untuk mencari pengaruh perlakuan tertentu terhadap yang lain dalam kondisi yang terkendalikan [9]. Pengujian kualitas permukaan hasil penyayatan mesin frais CNC pada material baja karbon rendah ST-37 ini dilakukan dengan dua macam metode, yakni metode downcut dan metode uppercut, menggunakan alat potong end mill HSS Ø $12 \mathrm{~mm}$ dan mesin frais CNC vertical FEELER VMP-40A kontrol FANUC Oi-MD, dengan mengvariasikan kecepatan putaran mesin dan feeding.

Dari setiap metode penyayatan divariasikan kecepatan putaran mesin sebanyak 3 variasi dan feeding sebanyak 3 variasi juga setiap metode penyayatan menggunakan 9 buah spesimen, maka didapatlah keseluruhan spesimen benda uji sebanyak 18 buah, dan pada stiap spesimen dilakukan pengujian kekasaran sebanyak 3 kali pada titik pengujian yang berbeda. Alat yang digunakan untuk pengujian kualitas permukaan baja ST-37, dengan menggunakan alat Surface Tester Mitutoyo SJ 201P. Metode penyayatan pada mesin Frais CNC sangat mempengaruhi kualitas permukaan benda kerja yang dihasilkan. Metode penyayatan tersebut terdiri dari dua macam yakni, metode downcut dan metode uppercut. Maka dari itu untuk mendapatkan kualitas permukaan yang maksimal harus mempertimbangkan gerak makan atau metode penyayatan.

\section{Kecepatan Putaran Spindle}

Kecepatan putaran spindle adalah jumlah putaran spindle per-satuan waktu [7]. Dirumuskan dengan:

$$
n=\frac{1000 \cdot C s}{\pi \cdot D}
$$

Kecepatan putaran dihitung berdasarkan Cutting speed (Cs). untuk baja karbon rendah nilai Cs berada pada kisaran 17-33 mm/menit [10], maka untuk Cs yang penulis ambil divariasikan sebnyak 3 variasi, yaitu 20, 25 dan 30. Maka,

1) Kecepatan putaran untuk Cs 20

$$
n=\frac{1000 \cdot C s}{\pi \cdot D}=\frac{1000 \cdot 20}{3,14 \cdot 12}=530,78 \mathrm{rpm}
$$


2) Kecepatan putaran untuk Cs 25

3) Kecepatan putaran untuk Cs 30

$$
n=\frac{1000 \cdot C s}{\pi \cdot D}=\frac{1000 \cdot 25}{3,14 \cdot 12}=663,48 \mathrm{rpm}
$$

$$
n=\frac{1000 \cdot C s}{\pi \cdot D}=\frac{1000 \cdot 30}{3,14 \cdot 12}=796,18 \mathrm{rpm}
$$

\section{Feeding}

Pemakanan (feeding) adalah jarak pemakanan cutter setiap putaran spindle [8]. Dirumuskan dengan:

$$
f=f Z \cdot Z \cdot n
$$

Feed per gigi yang disarankan pada proses frais baja dengan menggunakan pahat HSS (High Speed Steel) [8]. Pada penelitian ini Feeding divariasikan menjadi 3 variasi tiap kecepatan putaran mesin untuk feed per gigi nya diambil 0,05 mm, 0,04 mm, dan 0,03 mm. Maka feeding:

1) Feeding untuk kecepatan putaran mesin $530,78 \mathrm{rpm}$

$\mathrm{f}=\mathrm{fz} \cdot \mathrm{Z} \cdot \mathrm{n}=0,05 \times 4 \times 530,78=106,15 \mathrm{~mm} /$ menit

$\mathrm{f}=\mathrm{fz} \cdot Z \cdot \mathrm{n}=0,04 \times 4 \times 530,78=84,92 \mathrm{~mm} / \mathrm{menit}$

$\mathrm{f}=\mathrm{fz} . \mathrm{Z} \cdot \mathrm{n}=0,04 \times 4 \times 530,78=63,69 \mathrm{~mm} /$ menit

2) Feeding untuk kecepatan putaran mesin $663,48 \mathrm{rpm}$

$\mathrm{F}=\mathrm{fz} \cdot \mathrm{Z} \cdot \mathrm{n}=0,05 \times 4 \times 663,48=132,69 \mathrm{~mm} / \mathrm{menit}$

$\mathrm{F}=$ fz.Z.n $=0,04 \times 4 \times 663,48=106,15 \mathrm{~mm} /$ menit

$\mathrm{F}=\mathrm{fz} \cdot \mathrm{Z} \cdot \mathrm{n}=0,03 \times 4 \times 663,48=79,61 \mathrm{~mm} /$ menit

3) Feeding untuk kecepatan putaran mesin $796,18 \mathrm{rpm}$

$\mathrm{F}=\mathrm{fz} . \mathrm{Z} . \mathrm{n}=0,05 \times 4 \times 796,18=159,23 \mathrm{~mm} / \mathrm{menit}$

$\mathrm{F}=\mathrm{fz} \cdot \mathrm{Z} \cdot \mathrm{n}=0,04 \times 4 \times 796,18=127,38 \mathrm{~mm} /$ menit

$\mathrm{F}=\mathrm{fz} . Z . \mathrm{n}=0,03 \times 4 \times 796,18=95,54 \mathrm{~mm} / \mathrm{menit}$

Dalamnya penyayatan ditentukan, yaitu $1 \mathrm{~mm}$

Banyaknya penyayatan dalam satu spesimen sebanyak 3 kali.

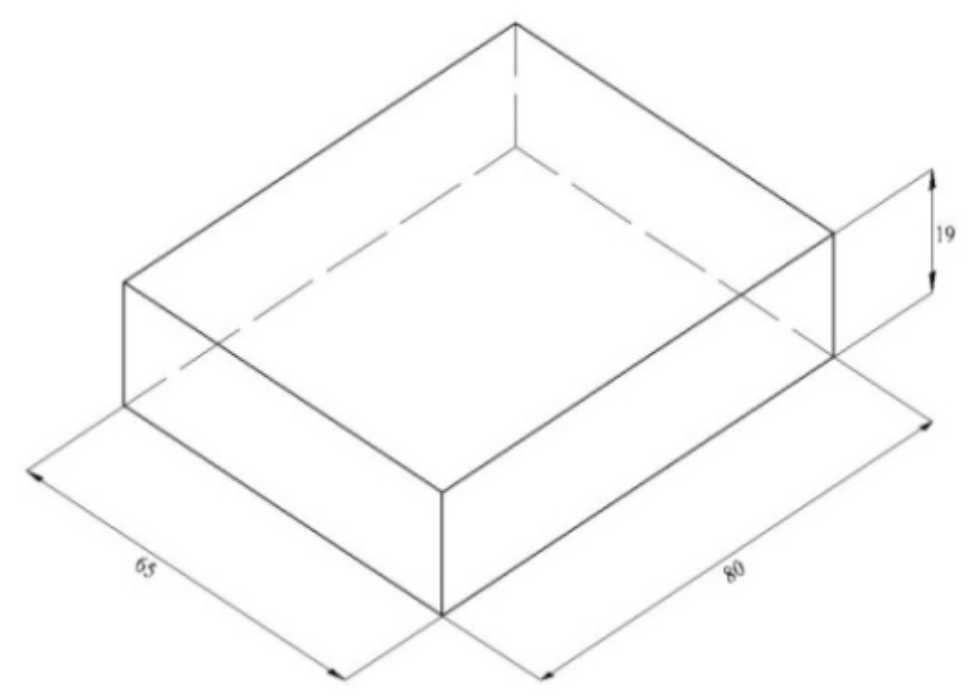

Gambar 1. Dimensi Material Bahan 


\section{Proses Pengefraisan}

Proses pengefraisan dilakukan setelah persiapan pengujian terpenuhi meliputi persiapan alat potong, benda uji, mesin frais CNC dan perlengkapannya beserta program, selanjutnya input program ke mesin, kemudian dilakukan proses penyayatan dengan variasi kecepatan potong dan feeding yang telah ditentukan. Pemotongan ini bertujuan untuk mendapatkan bentuk dasar spesimen yang akan di uji sesuai ukuran yang telah ditentukan yaitu $80 \mathrm{~mm} \times 65$ mm x 19 mm seperti pada Gambar 1.

Pengujian kualitas permukaan akan dilakukan dilaboratorium Metrologi Teknik Mesin Fakultas Teknik Universitas Negeri Padang. Setiap spesimen akan dilakukan pengujian sebanyak 3 kali dengan titik pengujian yang berbeda seperti terlihat pada Gambar 2 .

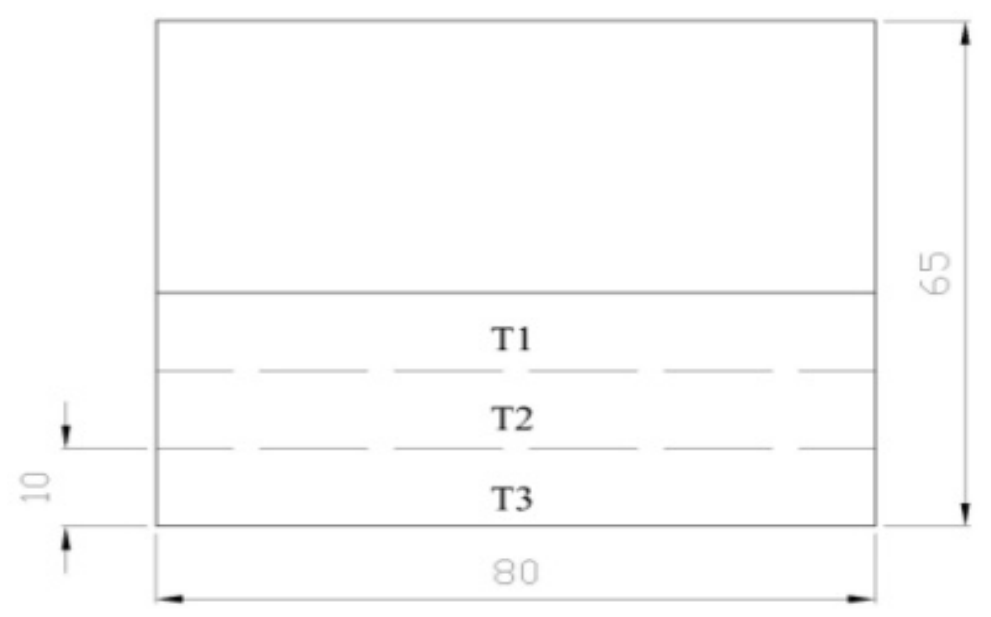

Keterangan:

a) Titik $\mathrm{T} 1$ = titik pengujian pertama

b) Titik T2 = titik pengujian kedua

c) Titik T3 = titik pengujian ketiga

Gambar 2. Titik Pengujian Kekasaran

Gambar 3 menunjukkan alat ukur yang digunakan yaitu surface tester merek Mitutoyo SJ-201P ketelitian 0,02 $\mu \mathrm{m}$

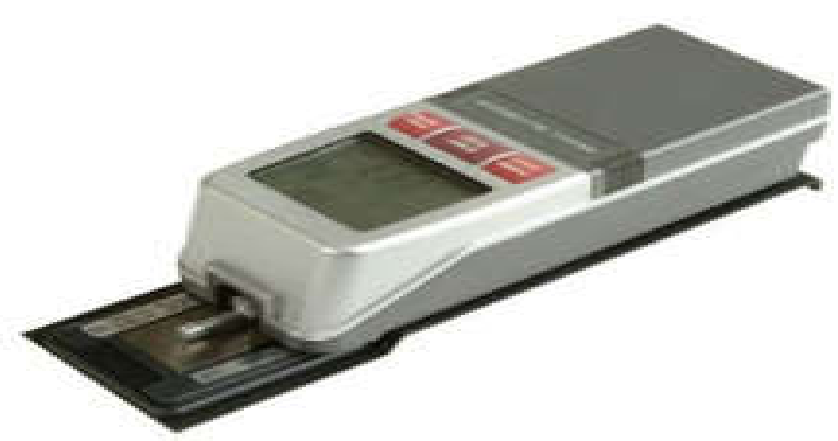

Gambar 3. Surface Tester Mitutoyo SJ-201P 
HASIL DAN PEMBAHASAN

\section{Hasil}

Tabel 1. Data hasil pengujian

\begin{tabular}{|c|c|c|c|c|c|c|c|c|}
\hline \multirow[t]{2}{*}{$\begin{array}{l}\text { Kedalaman } \\
\text { Pemakanan }\end{array}$} & \multirow[t]{2}{*}{$\begin{array}{c}\text { Metode } \\
\text { Penyayatan }\end{array}$} & \multirow{2}{*}{$\begin{array}{c}\text { Kecepatan } \\
\text { Putaran } \\
\text { (rpm) }\end{array}$} & \multirow[t]{2}{*}{$\begin{array}{c}\text { Feeding } \\
(\mathrm{mm} / \mathrm{mnt})\end{array}$} & \multicolumn{3}{|c|}{\begin{tabular}{|c} 
Tingkat Kualitas \\
Permukaan \\
Benda
\end{tabular}} & \multirow[t]{2}{*}{$\sum \mathrm{Ras}_{\mathrm{s}}$} & \multirow[t]{2}{*}{$\begin{array}{c}\text { Nilai } \\
\text { Kekasaran }\end{array}$} \\
\hline & & & & $\mathrm{T} 1$ & $\mathrm{~T} 2$ & T3 & & \\
\hline \multirow{24}{*}{$1 \mathrm{~mm}$} & \multirow{12}{*}{ Downcut } & \multirow{4}{*}{530,78} & a. 106,15 & 4,26 & 3,95 & 3,83 & 4,01 & \\
\hline & & & b. 84,92 & 4,05 & 3,74 & 3,77 & 3.85 & \\
\hline & & & c. 63,69 & 3,11 & 3,02 & 2,86 & 2,99 & \\
\hline & & & \multicolumn{4}{|c|}{$\sum \mathrm{Ra}_{\mathrm{p}}$} & 3,61 & N8 \\
\hline & & \multirow{4}{*}{663,48} & a. 132,69 & 2,93 & 2,84 & 2,75 & 2,84 & \\
\hline & & & b. 106,15 & 2,60 & 2,53 & 2,50 & 2,54 & \\
\hline & & & c. 79,61 & 2,43 & 2,40 & 2,41 & 2,41 & \\
\hline & & & \multicolumn{4}{|c|}{$\sum \mathrm{Rap}_{\mathrm{p}}$} & 2,59 & N8 \\
\hline & & \multirow{4}{*}{796,18} & a. 159,23 & 2,64 & 2,56 & 2,59 & 2,59 & \\
\hline & & & b. 127,38 & 2,35 & 2,39 & 2,42 & 2,38 & \\
\hline & & & c. 95,54 & 2,23 & 2,31 & 2,11 & 2,21 & \\
\hline & & & \multicolumn{4}{|c|}{$\sum \mathrm{Ra}_{\mathrm{p}}$} & 2,39 & N7 \\
\hline & \multirow{12}{*}{ Uppercut } & \multirow{4}{*}{530,78} & a. 106,15 & 3,25 & 3,31 & 3,26 & 3,27 & \\
\hline & & & b. 84,92 & 3,35 & 3,50 & 3,76 & 3,53 & \\
\hline & & & c. 63,69 & 4,26 & 5,33 & 5,50 & 5,03 & \\
\hline & & & \multicolumn{4}{|c|}{$\sum \mathrm{Ra}_{\mathrm{p}}$} & 3,94 & N8 \\
\hline & & \multirow{4}{*}{663,48} & a. 132,69 & 4,18 & 4,30 & 5,02 & 4,50 & \\
\hline & & & b. 106,15 & 5,28 & 5,20 & 5,88 & 5,45 & \\
\hline & & & c. 79,61 & 6,09 & 5,97 & 6,35 & 6,13 & \\
\hline & & & \multicolumn{4}{|c|}{$\sum \mathrm{Rap}$} & 5,36 & N9 \\
\hline & & \multirow{4}{*}{796,18} & a. 159,23 & 5,49 & 5,35 & 5,36 & 5,40 & \\
\hline & & & b. 127,38 & 5,95 & 5,98 & 6,04 & 5,99 & \\
\hline & & & c. 95,54 & 6,49 & 6,66 & 6,81 & 6,65 & \\
\hline & & & \multicolumn{4}{|c|}{$\sum \mathrm{Ra}_{\mathrm{p}}$} & 6,01 & N9 \\
\hline
\end{tabular}

\section{Pembahasan}

Berdasarkan Tabel 1, pengujian kualitas permukaan pada metode penyayatan downcut didapat nilai rata-rata kekasaran per kecepatan potong terendah adalah $\left(\sum \mathrm{Ra}_{\mathrm{p}}-\mathrm{min}\right)=2,39$ $\mu \mathrm{m}$ dengan kelas kekasaran $\mathrm{N7}$ dan nilai kekasaran tertinggi $\left(\sum \mathrm{Rap}\right.$-max $)=3,61 \mu \mathrm{m}$ dengan kelas kekasaran N8. Sedangkan pada metode penyayatan uppercut didapat nilai rata-rata kekasaran per kecepatan potong terendah adalah $\left(\sum \mathrm{Ra}-\mathrm{min}\right)=3,94 \mu \mathrm{m}$ dengan kelas 
kekasaran N8 dan nilai kekasaran tertinggi $\left(\sum \mathrm{Rap}_{\mathrm{p}} \mathrm{max}\right)=6,01 \mu \mathrm{m}$ dengan kelas kekasaran $\mathrm{N}$. Jadi nilai kekasaran yang dicapai dari hasil penelitian perbandingan kualitas permukaan hasil sayatan antara metode downcut dan uppercut mesin Frais CNC pada baja ST-37 adalah antara N7-N9 (ISO Roughness Number).

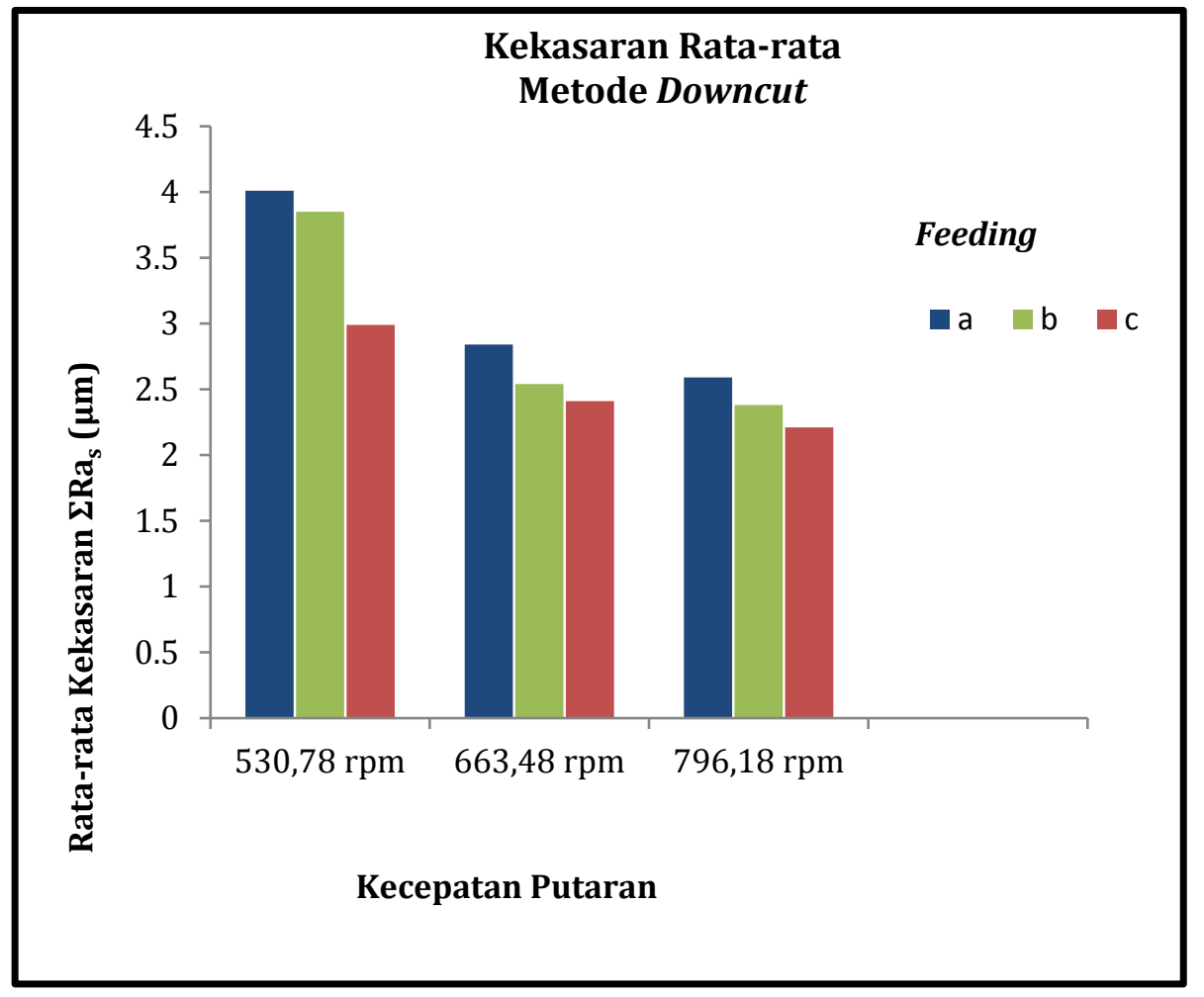

Gambar 4. Rata-rata kekasaran metode downcut

Metode penyayatan downcut menghasilkan permukaan yang lebih halus dibandingkan dengan metode penyayatan uppercut lebih jelas dapat dilihat pada Gambar 4 dimana harga rata-rata kekasaran per feeding terendah terdapat pada kecepatan putara 796,18 rpm dan feeding "c" (95,54 mm/mnt) dengan harga rata-rata kekasaran per feeding ( $\Sigma$ Ras $) 2,21 \mu \mathrm{m}$. Sedangkan rata-rata kekasaran per feeding tertinggi terdapat pada kecepatan putara 530,78 rpm dan feeding "a" (106,15 mm/mnt) dengan harga rata-rata kekasaran per feeding $\left(\Sigma \mathrm{Ra}_{\mathrm{s}}\right)$ 4,01 $\mu \mathrm{m}$. Pada metode ini lebih baik digunakan kecepatan putaran tinggi dan feeding rendah, karena arah dari putaran alat potong sama dengan arah gerak makan meja mesin. Bila konstruksi mesin kuat maka akan menghasilkan kualitas permukaan yang baik. Metode penyayatan downcut apabila semakin tinggi kecepatan putaran maka permukaan benda kerja yang dihasilkan akan lebih halus, dan apabila feeding yang semakin besar maka permukaan benda kerja yang dihasilkan semakin kasar.

Sedangkan Gambar 5 menunjukkan harga rata-rata kekasaran per feeding terendah terdapat pada kecepatan putara 530,78 rpm dan feeding "a" (106,15 mm/mnt) dengan harga rata-rata kekasaran per feeding $\left(\Sigma \mathrm{Ra}_{\mathrm{s}}\right) 3,27 \mu \mathrm{m}$. Sedangkan harga rata-rata kekasaran per feeding tertinggi terdapat pada kecepatan putara 796,18 rpm dan feeding "c"( 95,54 mm/mnt) dengan harga rata-rata kekasaran per feeding ( $\Sigma \mathrm{Ras}$ ) 6,65 $\mu \mathrm{m}$. Pada metode ini lebih baik digunakan kecepatan rendah, karena apabila putaran tinggi akan terjadi getaran yang mengakibatkan benda bergetar dan menyebabkan permukaan benda kerja menjadi lebih kasar. Metode penyayatan uppercut apabila kecepatan putaran diperbesar maka pernukaan akan semakin kasar dan jika feeding yang diperbesar maka permukaanya semakin halus, ini 
dikarenakan gesekan lebih pada alat potong yang mengakibatakan alat potong menjadi cepat tumpul karna kecepatan putaran yang berlebihan.

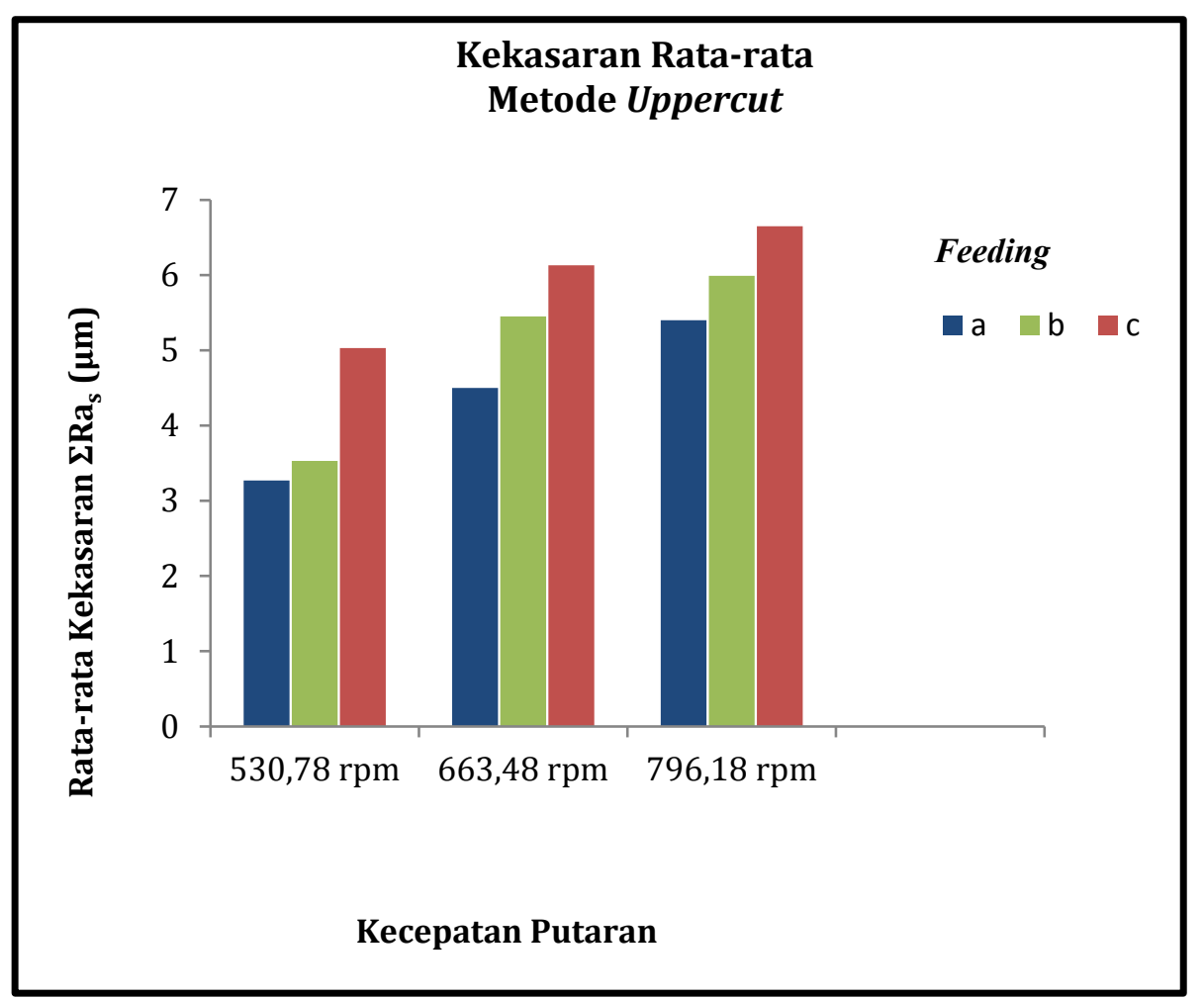

Gambar 5. Rata-rata kekasaran metode uppercut

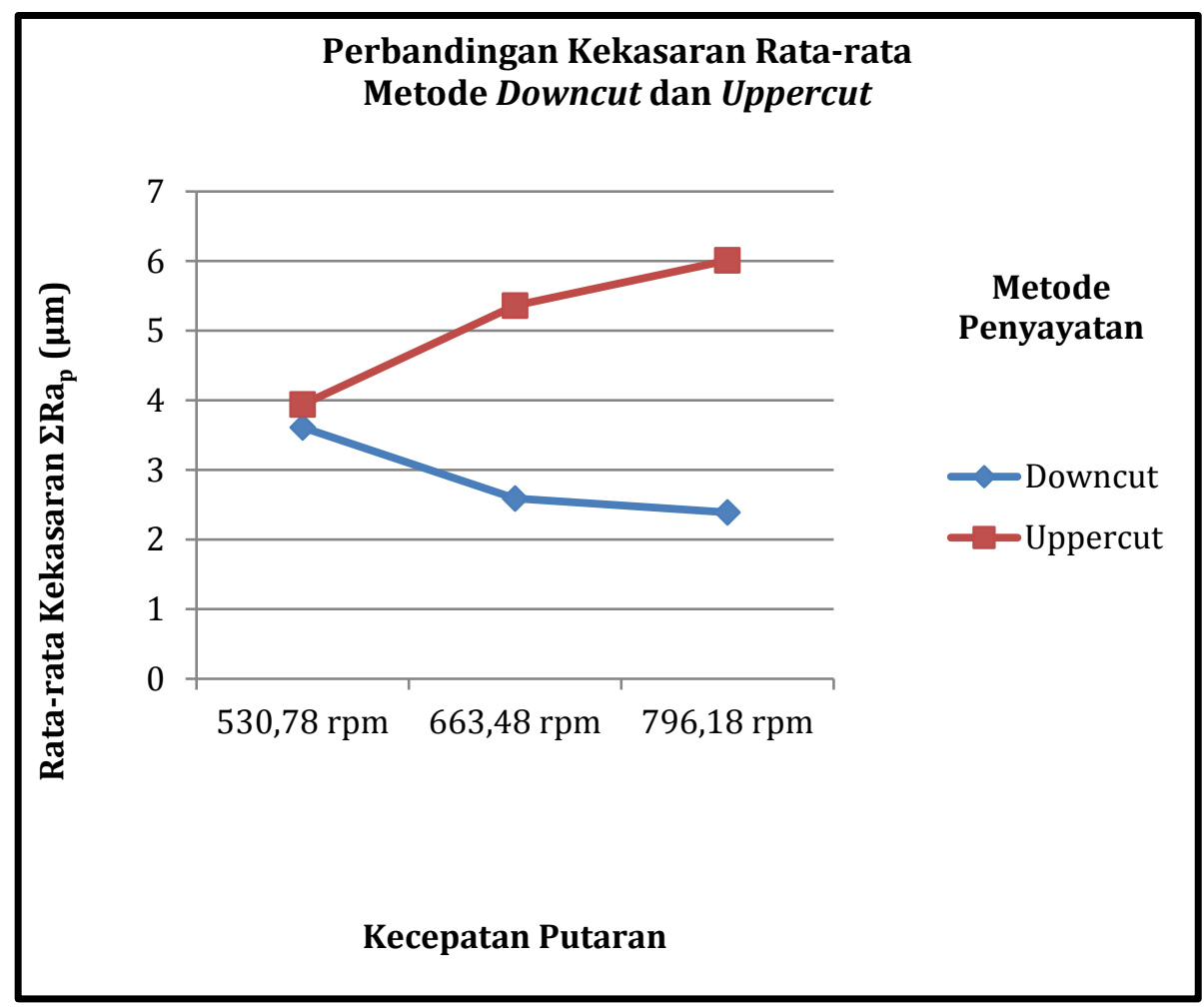

Gambar 6. Perbandingan kekasaran rata-rata metode downcut dan uppercut 
Metode downcut dan uppercut berbanding terbalik terhadap hasil penyayatanya lihat Gambar 6, apabila pada metode penyayatan downcut terlihat pada grafik semakin tinggi kecepatan putaran maka kualitas permukaan benda kerja yang dihasilkan semakin halus, dan pada metode penyatan uppercut apabila semakin tinggi kecepatan putaran maka kualitas pemukaan yang dihasilkan semakin kasar. Pada metode uppercut gesekan alat potong lebih besar dibandingkan dengan metode downcut yang menyebabkan alat potong menjadi cepat tumpul dan membuat permukaan benda kerja menjadi kasar. Tetapi apabila menggunakan metode penyayatan downcut mesin yang digunakan harus mempunyai konstruksi mesin yang baik, karna apabila konstruksi mesin kurang baik maka akan menimbulkan getaran yang dapat membuat permukaan benda kerja menjadi kasar bahkan dapat mematahkan alat potong. Oleh karna itu, mesin frais CNC memiliki konstruksi mesin yang baik, dapat disimpulkan bahwa dalam melakukan pengerjaan menggunakan mesin frais CNC lebih baik menggunakan metode penyayatan downcut.

\section{SIMPULAN DAN SARAN}

\section{Simpulan}

Terdapat perbedaan antara metode penyayatan downcut dan uppercut mesin Frais CNC terhadap kualitas permukaan benda kerja material baja ST-37 dengan variasi kecepatan putaran dan feeding. Dibuktikan dengan nilai Rap terendah pada metode downcut adalah 2,39 $\mu \mathrm{m}$ dan nilai $\mathrm{Ra}_{\mathrm{p}}$ tertingginya adalah $3,61 \mu \mathrm{m}$. Sedangkan pada metode uppercut nilai $\mathrm{Ra}_{\mathrm{p}}$ terendah adalah 3,94 $\mu \mathrm{m}$ dan nilai Rap tertingginya adalah 6,01 $\mu \mathrm{m}$.

Metode penyayatan downcut nilai kekasaran terendah adalah N7 dan nilai kekasaran tertinggi adalah N8. Sedangkan pada metode penyayatan uppercut nilai kekasaran terendah adalah N8 dan nilai kekasaran tertinggi adalah N9. Dari data tersebut dapat diambil kesimpulan bahwa metode downcut menghasilkan kualitas permukaan yang lebih baik dari pada metode uppercut.

Proses penyayatan downcut adalah semakin tinggi kecepatan putaran maka semakin halus permukaan benda yang dihasilkan, Sedangkan pada proses penyayatan uppercut semakin tinggi kecepatan putaran maka semakin kasar permukaan benda yang dihasilkan. pada proses penyayatan downcut adalah semakin rendah feeding maka permukaan yang dihasilkan semakin halus, Sedangkan pada proses uppercut semakin rendah feeding maka permukaan yang dihasilkan semakin kasar

\section{Saran}

Untuk mendapatkan hasil kekasaran yang baik (paling rendah) sebaiknya dalam proses finishing menggunakan feeding paling kecil. Untuk proses roughing sebaiknya digunakan feeding lebih besar karena untuk mengefisiensikan waktu dan biaya dalam proses pemesinan frais. Untuk penelitian tindak lanjut, sebaiknya digunakan pisau yang baru, karena pisau yang telah diasah mengalami penurunan kualitas hasil kekasaran pada feeding yang besar.

\section{DAFTAR RUJUKAN}

[1] E. Indrawan and R. Rifelino, "PENINGKATAN AKTIFITAS BELAJAR MAHASISWAMELALUI PENGGUNAAN MULTIMEDIA DALAM MATA KULIAH METROLOGI INDUSTRI," Penelit. Pendidik., vol. 5, no. 1, 2014, Accessed: May 07, 2020. [Online]. Available: http://ejournal.unp.ac.id/index.php/penelitianpendidikan/article/view/4132.

[2] B. S. Wijanarka, "PENGEMBANGAN MODUL DAN PEMBELAJARAN KOMPETENSI KEJURUAN TEKNIK PEMESINAN CNC SMK,” p. 63, 2012. 
[3] H. Soewito, Mesin Frais. Bandung: Defisi Pengembangan Bahan Ajar PPPG Teknologi Bandung, 1992.

[4] D. Rahdiyanta, "Buku 3 Proses Frais (Milling)," Jur. Pendidik. Tek. Mesin Univ. Negeri Yogyak., 2010.

[5] Y. A, E. Indrawan, N. Helmi, A. Aziz, and Y. A. Putra, "Pengaruh Sudut Potong dan Kecepatan Putaran Spindel Terhadap Kekasaran Permukaan pada Proses Bubut Mild Steel ST 37," INVOTEK J. Inov. Vokasional Dan Teknol., vol. 19, no. 2, pp. 29-36, Oct. 2019, doi: 10.24036/invotek.v19i2.582.

[6] A. Yufrizal, E. Indrawan, and N. Helmi, "Analysis Comparative Feeding Variation to Quality Surface Processes Blocking Equipment of Ems Steel 45on Cnc Latheing Machine," J. Phys. Conf. Ser., vol. 1387, p. 012100, Nov. 2019, doi: 10.1088/17426596/1387/1/012100.

[7] H. Mursidi and D. Jamaludin, Melakukan Pengerjaan Dengan Mesin Frais. Bandung: P4TK BMTI, 2012.

[8] Groover Mikel P., Fundamental of Modern Manufacturing: material, process and systems 4th edition. USA: John wiley and sons, Inc., 2010. 